\title{
Poblia section Cacodon (Mielichhoferiaceae, Bryophyta) with axillary bulbils in the Iberian Peninsula
}

\author{
by \\ Juan Guerra \\ Departamento de Biología Vegetal, Facultad de Biología, Universidad de Murcia, Campus de Espinardo, 30100 Murcia, Spain \\ jguerra@um.es
}

\begin{abstract}
Guerra, J. 2007. Pohlia section Cacodon (Mielichhoferiaceae, Bryophyta) with axillary bulbils in the Iberian Peninsula. Anales Jard. Bot. Madrid 64(1): 55-62.

A taxonomic and descriptive study is presented of the propaguliferous species -with axillary bulbils- of section Cacodon of the genus Pohlia in the Iberian Peninsula. Among the nine species of this section present in the Iberian Peninsula, seven produce axillary propagula (bulbils). The propagulum morphology, seen to be the most relevant gametophyte identification character, is described. Data are provided on the habitat and distribution of the species in the Iberian Peninsula, where they are considered rare or very rare.
\end{abstract}

Keywords: Pohlia, Pohlia section Cacodon, Bryophyta, Iberian Peninsula.

\section{Introduction}

The genus Poblia Hedw. (1801: 171), which has undergone substantial systematic and taxonomic changes that were summarized by Shaw (1984), has traditionally been included in Bryaceae (e.g. Brotherus, 1924). However, phylogenetic studies carried out with molecular markers, using plastid, mitochondrial and nuclear DNA sequences (Cox \& al., 2000, 2004), place the genus Poblia closer to Mniaceae. Its exclusion from Bryaceae has been proposed, along with Epipterigium Lindb. and Mielichhoferia Nees \& Hornsch. (cf. Shaw, 2005).

Shaw (1984) considered an infrageneric subdivision with three subgenera: Poblia, Nybolmiella Shaw and Mniobryum (Limpr.) Nyholm, the latter with two sections, Mniobryum and Cacodon Lindb. ex Broth. In Hill \& al. (2006) three sections are considered for the genus: Poblia, Cacodon and Apalo-

\begin{abstract}
Resumen
Guerra, J. 2007. Pohlia sección Cacodon (Mielichhoferiaceae, Bryophyta) con bulbillos axilares, en la Península Ibérica. Anales Jard. Bot. Madrid 64(1): 55-62 (en inglés).

Se realiza un estudio taxonómico y descriptivo de las especies con bulbillos axilares de la sección Cacodon del género Pohlia, existentes en la Península Ibérica. De las nueve especies de la sección presentes en el área, siete producen propágulos (bulbillos) de origen caulinar. Se describe la morfología de estos propágulos, que resulta ser el carácter más relevante para la identificación de las especies. Se aportan datos sobre hábitat y distribución en la Península Ibérica, donde pueden considerarse raras o muy raras.
\end{abstract}

Palabras clave: Pohlia, Pohlia sección Cacodon, Bryophyta, Península Ibérica.

dictyon (Müll. Hal.) Ochyra (= Mniobryum Nyholm, nom. inv.), and the genus Poblia is included in the family Mielichhoferiaceae, which closely reflects the criteria proposed by Koponen (1988).

The section Cacodon includes 15 species in Europe (cf. Hill \& al., 2006), of which 9 (P. andalusica (Höhn.) Broth., P. annotina (Hedw.) Lindb., P. camptotrachela (Renauld \& Cardot) Broth., P. drummondii (Müll. Hal.) A.L. Andrews, P. filum (Schimp.) Martensson, P. flexuosa Hook., P. lescuriana (Sull.) Ochi, P. ludwigii (Spreng. ex Schwägr.) Broth. and P. proligera (Kindb.) Lindb. ex Broth.) are found in the Iberian Peninsula. Except for P. lescuriana and $P$. ludwigii, the species of section Cacodon produce propagula in the form of axillary bulbils with their origin in the stem, which, when developed, permit the species to be identified quite easily. None of the species of the section Cacodon has been found with sporophytes in the Iberian Peninsula. 
In this article we provide morphological, chorological and ecological data that broaden the knowledge of these propaguliferous species in a territory where they are infrequent and probably undercollected.

\section{Material and Methods}

All the available material ( 65 specimens) of the studied species deposited in the Iberian herbaria have been studied. In addition, all the lectotypes of the species that it was possible to locate were studied. The bulbils were photographed with a SPOT INSIGHT U3.5 digital camera mounted on an OLYMPUS BH2 microscope. Measurement of the leaves, cells, etc., were made with a micrometer attached to the same microscope.

Substantial differences exist between the morphology of the propagula type in this group of Poblia, which, furthermore, tends to change as the bulbils mature (cf. Andrews, 1935; Nyholm, 1958; Wilczek \& Demaret, 1970; Crum, 1976; Townsend, 1995). Although the nomenclature to define the different types of axillary bulbils is similar in all the recent studies on the group (Wilczek \& Demaret, 1970; Lewis \& Smith, 1977, 1978; Demaret \& Wilczek, 1979, 1980; Shaw, 1981a, 1981b; Sotiaux \& Arts, 1989), in this paper, for the sake of simplicity, we have only distinguished the following two types of bulbil. Bulbil A) ovoid, elliptic, oblong, obconic, subspherical or cylindrical with laminate leaf primordia (Fig.1 a-k) and B) subspherical or obconic to vermicular with different degrees of spiralling and with toothlike leaf primordia, that is with apical teeth (Fig. 1 1-n; Fig. 2 a-o). Not only are the leaf primordia differences of primary importance, but also the form and size are important.

\section{Taxonomy}

Poblia Sect. Cacodon Lindb.ex Broth., Nat. Pflanzenfam. 1(3): 547. 1903

Poblia Sect. Pobliella Loeske, Stud. Morph. Syst. Laubm.: 125. 1910, nom. nud.

Type: Poblia erecta Lindb.

Small to moderately robust plants. Upper leaves usually similar to lower not forming comal tufts. Median laminal cells narrowly hexagonal-rhomboidal to linear or vermicular. Dioicous. Bulbils usually present. Capsule horizontal to pendulous, ovoid to pyriform; neck short. Exothecial cells short rectangular, with evenly thickened, sinuose walls; stomata superficial or rarely slightly sunken. Annulus differentiated. Endostome hyaline; segments well developed and keeled, rarely imperfect or rudimentary.

\section{KEY TO THE IBERIAN SPECIES}

1. Bulbils 1(2) in the axils of leaves, usually longer than $380 \mu \mathrm{m}$

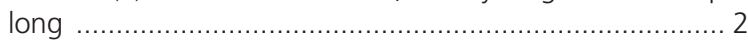

1. Bulbils usually numerous in the axils of leaves, usually shorter than $380 \mu \mathrm{m}$ long ...................................................... 3

2. Bulbils oblong to cylindrical, with laminate leaf primordia arising from base to apex ..................... 1. P. drummondii

2. Bulbils ovoid to elliptical or subspherical, with laminate leaf primordia arising only at the apex .................. 2. P. filum

3. Bulbils mainly isodiametric, spherical to short oblong, with 14 toothlike primordia of 1-2(3) cells .. 4. P. camptotrachela

3. Bulbils mainly long, obconic, oblong, ovoid or vermicular, sometimes all three types mixed in the same plant, with laminate leaf primordia of 3-6 cells wide at the base or with toothlike primordia

4. Bulbils mainly obconic, sometimes oblong, reddish to brownish, with laminate leaf primordia of 3-6 cells wide at the base

3. P. andalusica

4. Bulbils ovoid, shortly oblong or vermicular, greenish or reddish, with toothlike primordia .....

5. Plants with bulbils ovoid or shortly oblong in the axils of middle and lower leaves, and usually vermicular in the axils of upper leaves, toothlike primordia less than $1 / 10$ of bulbil length

5. P. flexuosa

5. Plants with only vermicular bulbils, toothlike primordia more than $1 / 10$ of bulbil length

6. Bulbils vermicular, mainly with 2-4(5) multicellular toothlike primordia

6. P. annotina

6. Bulbils vermicular, with 1(2) unicellular toothlike primordia ..

7. P. proligera

1. Pohlia drummondii (Müll. Hal.) A.L. Andrews, Moss Fl. N. Amer. 2: 196. 1935

Bryum drummondii Müll. Hal., Bot. Zeitung (Berlin) 20:328. 1862, basionym. Lectotype: BM!

(Fig. 1 a-d)

Plants 0.5-4.5(5) $\mathrm{cm}$ high, generally growing in loose turfs, sometimes dense, greenish, sometimes yellowish, slightly shiny when dry. Leaves appressed to more or less erect when dry, erect-patent when moist, ovate, rarely ovate-lanceolate, sometimes carinate, not or hardly decurrent, 0.8-1.5(1.8) × 0.2-0.5(0.7) $\mathrm{mm}$; apex acute, sometimes slightly obtuse, not twisted; margins plane, sometimes slightly recurved at the base, very slightly denticulate towards the apex, entire in lower half; upper leaves similar to the lower leaves. Costa 5660(70) $\mu \mathrm{m}$ wide near leaf base, ending below apex; cross section rounded. Upper and middle laminal cells long-rhomboidal to linear, sometimes long oblong, 35 $85(90) \times 6-10 \mu \mathrm{m}$, walls $(0.9) 1.2-1.5 \mu \mathrm{m}$ wide; basal cells mainly rectangular, sometimes long rhomboidal, 86-100 × (8)12-14 um; alar cells long-rectangular, 30-50 $\times 8-10(12) \mu \mathrm{m}$. Bulbils $1(2)$ in the axils of upper leaves, oblong to cylindrical, (350)400-700(1000) $\mu \mathrm{m}$ long, red -when fresh and alive- to brownish, opaque, with laminate leaf primordia arising from base to apex. 


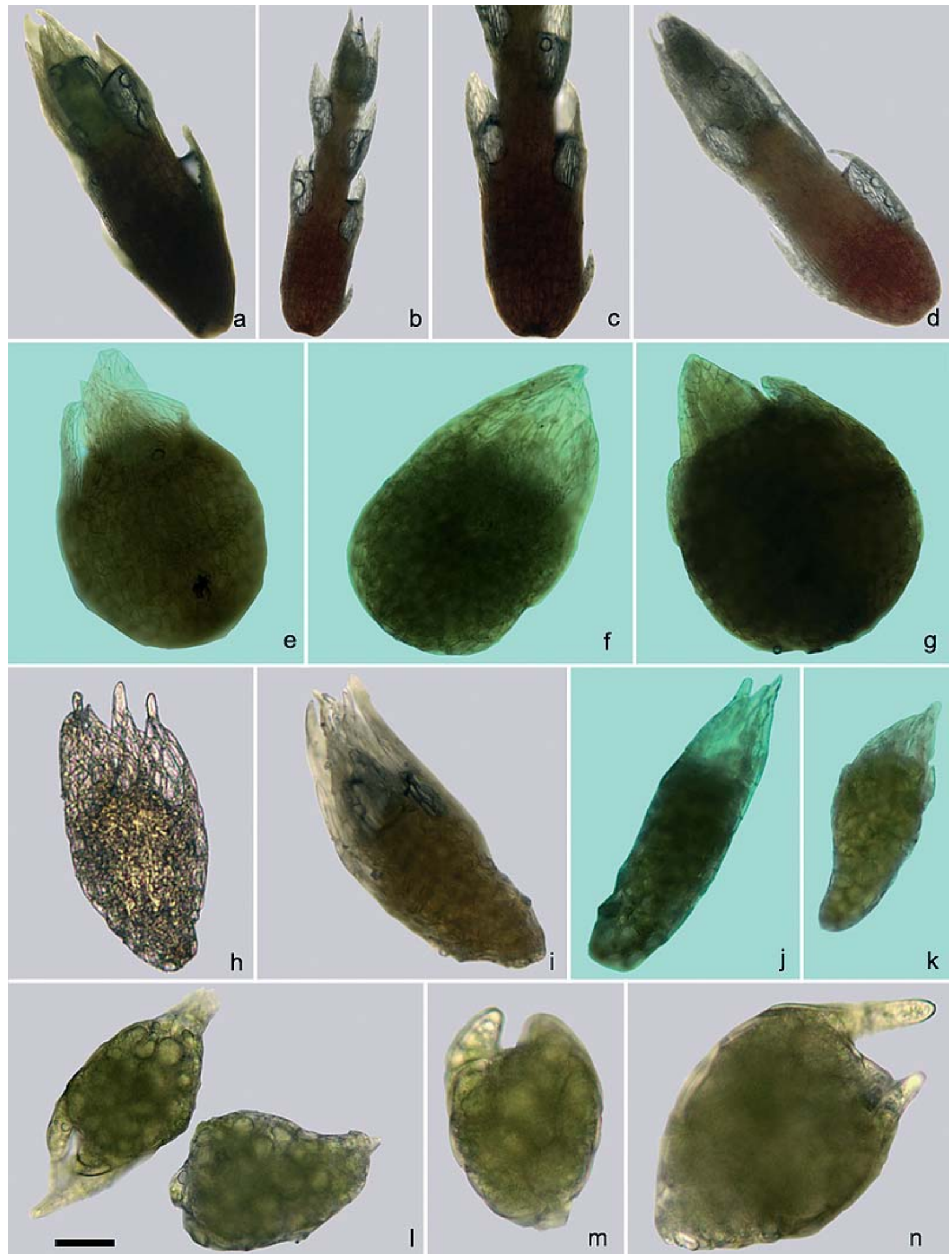

Fig. 1. Pohlia drummondii (MUB 18549): a-d, bulbils. P. filum (MUB 21458): e-g, bulbils. P. andalusica (MUB 21460): h-k, bulbils. P. camptotrachela (MACB 14339): I-n, bulbils. Scale: a, b, d-g = $100 \mu \mathrm{m} ; \mathrm{c}=70 \mu \mathrm{m} ; \mathrm{h}-\mathrm{k}=80 \mu \mathrm{m} ; \mathrm{I}-\mathrm{n}=30 \mu \mathrm{m}$. 

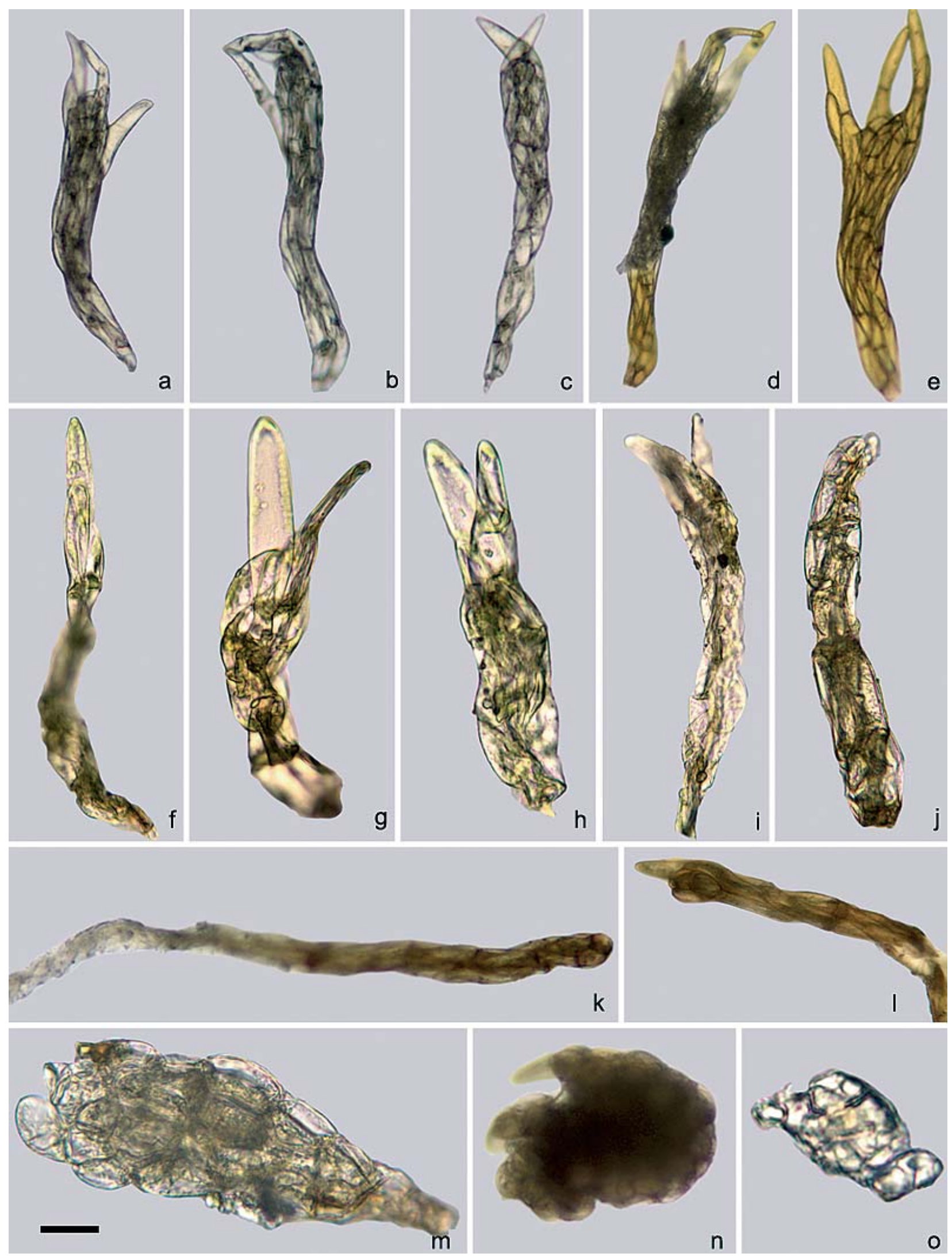

Fig. 2. Pohlia annotina (MA 7549): a-e, bulbils. P. proligera (MUB 1584): f-i, bulbils. P. flexuosa (MUB 21471): j-I, vermicular bulbils; $\mathbf{m}, \mathbf{n}$, sinuous outline bulbils; $\mathbf{o}$, bulbils angular outline with papillae. Scale: $a-e=35 \mu \mathrm{m} ; \mathrm{f}-\mathrm{i}=35 \mu \mathrm{m} ; \mathrm{j}=25 \mu \mathrm{m} ; \mathrm{k}, \mathrm{l}, \mathrm{n}, \mathrm{o}=30 \mu \mathrm{m} ; \mathrm{j}=$ $20 \mu \mathrm{m} ; \mathrm{m}=12 \mu \mathrm{m}$. 
Habitat. On sandy, acid and very wet soils on stream banks, in high mountains of the northern Iberian Peninsula. Infrequent in the Iberian Peninsula.

2. Pohlia filum (Schimp.) Martensson, Kung. Svenska Vetenskapsakad. Avh. Naturskyddsärenden 14: 149. 1956

Bryum filum Schimp., Syn. Musc. Eur. (ed. 2): 470. 1876, basionym. Lectotype designated by Shaw (1981): BM!

(Fig. 1 e-g)

Plants $1.5-5(6) \mathrm{cm}$ high, growing generally in loose turfs, sometimes dense, greenish, sometimes yellowish or orange, slightly shiny when dry. Leaves mainly appressed, sometimes erect when dry, erect to erect-patent when moist, ovate to ovate-lanceolate, usually carinate, decurrent, very pronunced on lower leaves, (1)1.2-1.8(1.9) × 0.2-0.5(0.7) $\mathrm{mm}$; apex acute, very rarely obtuse in young leaves, not twisted; margins plane, sometimes slightly recurved at the base, slightly denticulate towards the apex; entire in lower half; upper leaves similar to rest. Costa (48)5060(65) $\mu \mathrm{m}$ wide near leaf base, ending below apex; cross section rounded. Upper and middle laminal cells long rhomboidal to linear, 40-86(95) $\times(7) 10$ 12(14) $\mu \mathrm{m}$, walls $0.8-0 .(1.2) \mu \mathrm{m}$ wide; basal cells mainly rectangular, (80)90-100(110) × 10-14 $\mu \mathrm{m}$; alar cells mainly rectangular, 30-60 × 8-10 $\mu \mathrm{m}$. Bulbils solitary in the axils of upper leaves, ovoid to elliptical or subspherical, (300)350-500(550) $\mu \mathrm{m}$ long, brownish, opaque, with laminate leaf primordia arising only in the apex.

Habitat. Generally on sandy, acid and very wet soils on stream banks and, in very clear running water in high mountains of the northern Iberian Peninsula, sometimes on humid banks permanently covered with melting snow. A very rare species in the Iberian Peninsula; only known from the Pyrenees and north Portugal.

Observations. Poblia filum is difficult to distinguish from $P$. drummondii in the absence of bulbils, which have a characteristic shape. P. filum is reported to have more decurrent and appressed leaves (cf. Lewis \& Smith, 1978; Shaw, 1981; Nordhorn-Richter, 1982) and this is also the case in Iberian specimens.

3. Pohlia andalusica (Höhn.) Broth., Nat. Pflanzenfam. 1(3): 551. 1903

Webera andalusica Höhn., Sitzungsber. Kaiserl. Akad. Wiss. Math.-Naturwiss. Cl. Abt. 1. 104: 326. 1895, basionym. Lectotype: FH!

(Fig. 1 h-k)
Plants 0.3-0.8(1.2) $\mathrm{cm}$ high, growing in loose turfs or gregariously in tufts, greenish-yellow, sometimes reddish at base, slightly or not all shiny when dry. Leaves erect when dry, erect to erect-patent when moist, ovate, rarely ovate-lanceolate, sometimes slightly carinate, hardly decurrent, 0.7-0.8(0.9) × 0.3 $0.4(0.5) \mathrm{mm}$; apex acute, sometimes slightly twisted; margins plane, sometimes slightly recurved at the base and in upper third, denticulate towards the apex, entire in lower half; upper leaves similar to the rest. Costa (25)30-35 $\mu \mathrm{m}$ wide near leaf base, ending below apex; cross section rounded. Upper and middle laminal cells long rhomboidal to linear-rectangular, sometimes short-vermicular, (40)50-80(90) × 6-8(10) $\mu \mathrm{m}$, walls $1-1,2 \mu \mathrm{m}$ wide; basal cells mainly rectangular,(30)40-50(54) × 8-10(12) $\mu \mathrm{m}$; alar cells mainly short rectangular, 30-40 × 8-10 $\mu \mathrm{m}$. Bulbils (1)2-3(4) in the axils of upper leaves, rarely in lower leaves, mainly obconic, sometimes oblong, (200)400$500(600) \mu \mathrm{m}$ long, reddish to brownish, opaque to semi-transparent, with laminate leaf primordia of 3-6 cells wide at the base, arising only at the apex.

Habitat. Acid soils, sometimes calcareous, on talus and in bare patches in pastures and meadows, generally shaded, humid sites in high and medium mountains. Relatively frequent in the Iberian Peninsula.

Observations. Obconic bulbils, with leaf primordia arising only in the apex is a characteristic of Poblia andalusica and therefore useful for identification purposes.

4. Pohlia camptotrachela (Renauld \& Cardot) Broth., Nat. Pflanzenfam. 1(3): 552. 1903

Webera camptotrachela Renauld \& Cardot, Bot. Gaz.

13(8): 199. 1888, basyonim. Isotype: NY! (Fig. 11 -n)

Plants 1-1.2(1.5) cm high, growing in loose turfs, green to yellowish, sometimes orange at base, not shiny when dry. Leaves erect when dry, erect to erectpatent when moist, generally narrow ovate-lanceolate, non carinate, not to clearly decurrent, (0.6)0.7$0.8(0.9) \times 0.2-0.25(0.35) \mathrm{mm}$; apex acute, not twisted; margins plane, denticulate toward the apex, entire in lower half; upper leaves slightly broader than rest. Costa (28)30-35(40) $\mu \mathrm{m}$ wide near the base, ending below apex or percurrent; cross section rounded. Upper and middle laminal cells long rhomboidal to linear, sometimes short vermicular, 66-82(98) × 6-7(8) $\mu \mathrm{m}$, walls $1-1,2 \mu \mathrm{m}$ wide; basal cells mainly rectangular, 45-55 × 8-9 $\mu \mathrm{m}$; alar cells rectangular, 35-40 × 8-9 $\mu \mathrm{m}$. Bulbils generally in groups of 5-6(7) in axils of upper and middle leaves, rarely solitary, mainly iso- 
diametric, spherical to shortly oblong, (100)125150(200) $\mu \mathrm{m}$ long, greenish to yellowish, transparent, with 1-4 toothlike primordia of 1-2(3) cells, occasionally laminate primordia with age.

Habitat. Acid soils, on taluses and on bare ground in pastures and meadows, shaded, wet sites generally near streams and springs. Relatively frequent in the Iberian Peninsula.

Observations. Poblia annotina may occasionally produce similar bulbils to those of $P$. camptotrachela, but are mixed with typical bulbils of the species, and never spherical to oblong, so there need be no confusion.

5. Pohlia flexuosa Hook. f., Icon. Pl. 1, pl. 19, f. 5. 1836

Lectotype: designated by Long on the sheet: TCD!

Poblia muyldermansii R. Wilczek \& Demaret, Bull. Jard. Bot. Belg. 40: 417. 1970

(Fig. 2 j-o)

Plants $1.5-2 \mathrm{~cm}$ high, growing in loose turfs, yellowish green to green pale, sometimes orangey at base, not shiny when dry. Leaves erect when dry, erect to erect-patent when moist, ovate-lanceolate, non carinate, strongly decurrent, $0.8-0.9(1.2) \times 0.4-0.5 \mathrm{~mm}$; apex acute, not twisted; margins more or less recurved, slightly denticulate towards apex, entire in lower two-thirds; upper leaves broader than rest. Costa 42-50(55) $\mu \mathrm{m}$ wide near leaf base, ending below apex or subpercurrent; cross section rounded. Upper and middle laminal cells long rhomboidal, more or less linear near the margins, 45-75(95) × (6)8-14(20) $\mu \mathrm{m}$, walls 1.2-1.8 $\mu \mathrm{m}$ wide; basal cells rectangular to long rhomboidal, (35)40-60(65) $\times(8) 14-15 \mu \mathrm{m}$, alar cells long rectangular, 60-70 $\times 8-9 \mu \mathrm{m}$. Bulbils usually numerous, normally in axils of middle and lower leaves, ovoid or shortly oblong, some more or less sinuous outline, brownish, transparent to almost opaque, others angular in outline, with small papillose protuberances, 90-100(110) $\mu \mathrm{m}$ long, hyaline, and a third type generally in the axils of upper leaves, vermicular, (150)200-300(350) $\mu \mathrm{m}$ long, brownish, more or less transparent, with 1-2 unicellular toothlike primordia very short, not reaching 1/10 of bulbil length.

Habitat. Acid soils on very humid, shaded taluses.

Observations. Only known from two localities in the Iberian Peninsula, one near Girona (Casas, 1996) and that studied here.

Pohlia flexuosa produces up to three diferent types of bulbil, usually mixed (at least in material studied) in the axils of upper and middle leaves. These types have been interpreted as different stages of propagule development (Wilczek \& Demaret, 1970; Townsend, 1995). However, in Smith (2004) and Hill \& al. (2006) these propagule types are given taxonomic value to differentiate two varieties of Pohlia flexuosa: var. flexuosa and var. pseudomuyldermansii (Arts, Nordhorn-Richter \& A.J.E. Sm.) A.J.E. Sm.

The vermicular propagules of $P$. flexuosa look like those of $P$. proligera, although the latter are broader [(10-15(20) $\mu \mathrm{m}$ in P. flexuosa and 30-35 $\mu \mathrm{m}$ in P. proligera] and the apical cells are much longer.

6. Pohlia annotina (Hedw.) Lindb., Musci Scand.: 17. 1879

Bryum annotinum Hedw., Sp. Musc. Frond.: 183, pl. 43. 1801, basyonim. Lectotype designated by Shaw (1981): G. Not seen.

(Fig. 2 a-e)

Plants 1-2 cm high, growing in loose turfs, yellowish to slightly orange or reddish at the base, slightly shiny when dry. Leaves erect-patent to spreading when dry, patent to spreading when moist, lanceolate to ovate-lanceolate, non carinate, non or slightly decurrent, (1.2)1.4-1.5 × 0.3-0.4(0.45) $\mathrm{mm}$; apex acute, sometimes twisted; margins plane, sometimes slightly recurved at the base, sinuous-denticulate in upper third, entire in lower half; upper leaves narrower and shorter than rest. Costa 50-60 $\mu \mathrm{m}$ wide near leaf base, ending below the apex or percurrent, cross section rounded to semicircular. Upper and middle laminal cells mainly linear, sometimes vermicular, (60)80$120(130) \times 6-8(11) \mu \mathrm{m}$, walls $1.5-2 \mu \mathrm{m}$ wide; basal cells long rhomboidal to rectangular, (30)35-55 × 7.5$8(8.5) \mu \mathrm{m}$; alar cells long rectangular to short linear, $50-65 \times 7.5-8 \mu \mathrm{m}$. Bulbils usually numerous, in axils of middle and upper leaves, vermicular, obconic, 50$100(250) \mu \mathrm{m}$ long, almost hyaline to yellowish, transparent, with 2-4(5) multicellular toothlike primordia, sometimes in axils of middle leaves or mixed, bulbils oblong or obconic, non vermicular, 50-60 $\mu \mathrm{m}$ long, yellowish, transparent, with 2-3(4) generally multicellular toothlike primordia.

Habitat. Acid soils, sometimes calcareous on humid and shaded taluses.

Observations. Probably the most frequent occurring species of those studied here.

7. Pohlia proligera (Kindb.) Broth., Nat. Pflanzenfam. 1(3): 551. 1903

Webera proligera Kindb., Forh. Vidensk.-Selsk. Kristiana 1886(6): 30. 1888, basionym. Type: not seen. (Fig. 2 f-i) 
Plants $0.3-1(2.5) \mathrm{cm}$ high, growing in loose turfs, greenish to reddish at the base, shiny when dry. Leaves erect to patent when dry, erect-patent when moist, narrowly lanceolate to slightly ovate-lanceolate, carinate near the base, non decurrent, 0.9$1.2(1.5) \times(0.2) 0.25-0.3 \mathrm{~mm}$; apex acute, sometimes very slightly twisted; margins plane, sometimes slightly recurved at the base, denticulate near the apex, entire to sinuous-denticulate in lower third; upper leaves slightly longer and broader than rest. Costa (24)28-34 $\mu \mathrm{m}$ wide near base, ending below apex, percurrent or slightly on oldest leaves, cross section plane to convex. Upper and middle laminal cells long rhomboidal to linear-vermicular, (60)74-90(100) $\times(4) 5-9(10) \mu \mathrm{m}$, walls $1-1.25 \mu \mathrm{m}$ wide; basal cells long rhomboidal to rectangular, (38)40-60 × 8-9(10) $\mu \mathrm{m}$; alar cells long rectangular to linear, $80-90 \times 4-6 \mu \mathrm{m}$. Bulbils usually numerous, in axils of upper leaves, vermicular, subcylindrical, 50-100(250) $\mu \mathrm{m}$ long, hyaline, with 1(2) unicellular toothlike primordia.

Habitat. Acid soils, sometimes calcareous on wet and shaded taluses, frequently covered with herbaceous vegetation. Poblia proligera is a much more northern species, and in the Iberian Peninsula only appear at higher elevations compared to $P$. annotina.

Observations. The bulbils of this species are characteristic, although they may resemble those Poblia annotina in the early stages of development. It is therefore necessary to observe a considerable number of bulbils to avoid confusion. Another character to dis- tinguish $P$. proligera from $P$. annotina is the very shiny leaves of $P$. proligera, which permits a distinction even when bulbils are lacking.

\section{Conclusions}

To date, a group of seven species of Poblia from the section Cacodon can be characterized in the Iberian Peninsula according to differences in size, number, morphology, etc. of their axillary bulbils. Species of this group are very similar to one another in such features as habit, size, leaf sheen, shape, leaf cell size and shape. In most cases species are not easily recognizable in the absence of bulbils. Table 1 summarises the most relevant differentiating characteristics of all the species studied.

\section{Selected specimens studied}

\section{Poblia drummondii}

SPAIN. Cantabria: Vega de Liébana, Peña Prieta, 2350 m, entre pizarras en la vertiente N, Muñoz (MA 19350). Huesca: Benasque, $2700 \mathrm{~m}$, rezumos y regatos en la cara sur de la brecha de Llosás, granitos, Heras (VIT 6877). Lérida: Alta Ribagorza, La Renclusa, 2000 m, Casas (MA 27809). Palencia: Laguna de Fuentes Carrionas, 2200, Cano (MUB 18549).

\section{Poblia filum}

SPAIN. Huesca: Benasque, entre los ibones y el Pico de la Renclusa, hendiduras de rocas rezumantes cerca de un nevero, $2350 \mathrm{~m}$, Guerra (MUB 21458). Pyréneés, Maladetta, Zetterstedt s.n. (UPS). Pyréneés, Maladetta, Jones s.n. (BM).

Table 1. Diagnostic characters of Pohlia section Cacodon in the Iberian Peninsula.

\begin{tabular}{|c|c|c|c|c|}
\hline Species & Leaf shape & $\begin{array}{l}\text { Shape \& width of median } \\
\text { laminal cells }\end{array}$ & Bulbil shape & $\begin{array}{c}\text { Costa } \\
\text { width }(\mu \mathrm{m})\end{array}$ \\
\hline P. drummondii & $\begin{array}{c}\text { Ovate, rarely } \\
\text { ovate-lanceolate }\end{array}$ & $\begin{array}{c}\text { Long rhomboidal to linear, sometimes } \\
\text { long oblong / 6-8 } \mu \mathrm{m}\end{array}$ & $\begin{array}{c}\text { Oblong to cylindrical, with laminate leaf } \\
\text { primordia arising from base to apex }\end{array}$ & $56-60(70)$ \\
\hline P. filum & $\begin{array}{c}\text { Ovate to } \\
\text { ovate-lanceolate }\end{array}$ & $\begin{array}{l}\text { Long rhomboidal to linear / } \\
\text { (7) } 10-12(14) \mu \mathrm{m}\end{array}$ & $\begin{array}{c}\text { Ovoid to eliptical or subspherical, with } \\
\text { laminate leaf primordia arising only } \\
\text { in the apex }\end{array}$ & $\begin{array}{l}(48) 50- \\
60(65)\end{array}$ \\
\hline P. andalusica & $\begin{array}{c}\text { Ovate, rarely } \\
\text { ovate-lanceolate }\end{array}$ & $\begin{array}{c}\text { Long rhomboidal to linear-rectangular, } \\
\text { sometimes short vermicular / } \\
6-8(10) \mu \mathrm{m}\end{array}$ & $\begin{array}{l}\text { Obconic, sometimes oblong, with } \\
\text { laminate leaf primordia arising only } \\
\text { in the apex }\end{array}$ & (25)30-35 \\
\hline P. camptotrachela & Ovate-lanceolate & $\begin{array}{l}\text { Long rhomboidal to linear, sometimes } \\
\text { short vermicular / 6-7(8) } \mu \mathrm{m}\end{array}$ & $\begin{array}{l}\text { Spherical to short oblong, with 1-4 } \\
\text { toothlike leaf primordia of } 1-2(3) \text { cells }\end{array}$ & $\begin{array}{l}(28) 30- \\
35(40)\end{array}$ \\
\hline P. flexuosa & Ovate-lanceolate & Long rhomboidal / (6)8-14(20) $\mu \mathrm{m}$ & \begin{tabular}{|c|} 
Vermicular with 1-2 unicellular \\
toothlike primordia, or ovoid to oblong, \\
more or less sinuous outline or papillae
\end{tabular} & $42-50(55)$ \\
\hline P. annotina & $\begin{array}{l}\text { Lanceolate to } \\
\text { ovate-lanceolate }\end{array}$ & $\begin{array}{l}\text { Mainly linear, sometimes } \\
\text { vermicular / 6-8(11) } \mu \mathrm{m}\end{array}$ & $\begin{array}{c}\text { Vermicular, rarely obconic with 2-4(5) } \\
\text { multicellular toothlike primordia }\end{array}$ & $50-60$ \\
\hline P. proligera & $\begin{array}{l}\text { Narrowly lanceolate to } \\
\text { slightly ovate-lanceolate }\end{array}$ & $\begin{array}{l}\text { Long rhomboidal to linear-vermicular } \\
\qquad /(4) 5-9(10) \mu \mathrm{m}\end{array}$ & $\begin{array}{l}\text { Vermicular to subcylindrical, with } \\
1(2) \text { unicellular toothlike primordia }\end{array}$ & (24)28-34 \\
\hline
\end{tabular}




\section{Poblia andalusica}

ANDORRA: Port de Cabús, 2350 m, Casas (MA 20255). SPAIN. Granada: Sierra Nevada, Rams (MUB 18578). Huesca: Benasque, ibones de la Renclusa, 2280 m, Guerra (MUB 21460). Pyrénées centrales, Port de Venasque, Zettersdedt s.n. (UPS). Lérida: Esterri de Cardós, 1000 m, Casas (MUB 21463).

\section{Poblia camptotrachela}

SPAIN. Ávila: Puerto del Pico, Cuevas del Valle, Fuente Mariblanca, Soria E Ron (MACB 14339). Granada: Sierra Nevada, Loma W del Mulhacén, 3150 m, Rams (MUB 21218).

\section{Pobliaflexuosa}

SPAIN. Huesca: Valle de Hecho, Selva de Oza, talud en un camino, Guerra (MUB 21471).

\section{Poblia annotina}

PORTUGAL. Serra da Estrela, entre Gouveia y Manteigas, 1350 m, talud en el borde de un arroyo, Guerra et al. (MUB 22534). SPAIN. Burgos: Huidobro, suelos ácidos en el melojar, Fuertes Lasala (MACB 32463). Cáceres: camino de Guadalupe a Navalvillar de Ibor, estribaciones de la Sierra de Viejas, Viera (MUB 2530). Guipúzcoa: Eibar, Arrate, talud sobre basaltos, $570 \mathrm{~m}$, Infante E Heras (VIT 20190). Huesca: Benasque, camino al Ibón de Gorgutes, 1700 m, Guerra (MUB 21465). Logroño: Villanueva de Cameros, Arroyo del Hoyo, 900 m, Martínez Abaigar (Herb. Martínez Abaigar s.n.). Lugo: Ancares, camino de Campo da Braña a Piornedo, 1100 m, taludes, Casañ E Puche (VAL 1746). Madrid: Lozoya del Valle, talud junto a un arroyo, $1200 \mathrm{~m}$, Jorquera E Lara (MA 7549). Navarra: Goizueta, borde un camino, de Miguel \& Edera (PAMP 4425). Zamora: Galende, Laguna de los Peces, $1700 \mathrm{~m}$, en taludes bajo brezos, humícola, Infante \& Heras (VIT 24692).

\section{Poblia proligera}

SPAIN. Albacete: Campamento de San Juan, Sierra del Calar del Mundo, 1200, talud ácido protegido por herbáceas, Jiménez \& Ros (MUB 1584). Almería: Sierra de los Filabres, Bacares, Barranco del Pino, García-Zamora E Ros (MUB 8643). Almería, Sierra de Filabres, Bacares, Barranco de Julián, 1600-1700 m, tierra acumulada en un muro muy protegido, García-Zamora E Ros (MUB 8557). Guadalajara: hayedos de Cantalojas, $1500 \mathrm{~m}$, Riestra (MACB s.n.).

\section{Acknowledgements}

We are very grateful to A. Jonathan Shaw for examining some samples, Mark Hill for corrections to a previous version of the manuscript, and the curator of the herbaria cited for the loan of samples. This work has been carried out with financial support of Ministerio de Educación y Ciencia (Proyect CGL200600599/BOS, Flora Briofítica Ibérica).

\section{References}

Andrews, A.L. 1935. Bryaceae. In: Grout, A.J. (ed.), Moss Flora of North America North of Mexico, vol. 2. Newfane.

Brotherus, V.F. 1924. Musci. In: Engler, A. \& Prantl, K. (eds.), Die natürlichen Pflanzenfamilien, vol. 2. Lipsiae.

Casas, C. 1996. Modificaciones a "New checklist of spanish mosses" III. Boletín de la Sociedad Española de Briología 9: 8-10.
Cox, C.J., Goffinet, B., Newton, A.E., Shaw, A.J. \& Hedderson, J. 2000. Phylogenetic relationships among the diplolepidousalternate mosses (Bryidae) inferred from nuclear and chloroplast DNA sequences. The Bryologist 103: 224-240.

Cox, C.J., Goffinet, B., Shaw, A.J. \& Boles, S. 2004. Phylogenetic relationships among the mosses based on heterogeneous Bayesian analysis of multiple genes from multiple genomic compartments. Systematic Botany 29: 234-250.

Crum, H.A. 1976. Mosses of the Great Lakes Forest, ed. 2. Ann Arbor.

Demaret F. \& Wilczek, R. 1979. Les Pohlia de Belgique. Bulletin du Jardin Botanique. National de Belgique 49: 149-158.

Demaret F. \& Wilczek, R. 1980. Confusions possibles dans la determination de certaines espèces propaguliferes de Pohlia et de Bryum. Dumortiera 14-15: 1-5

Hill, M.O., Bell, N., Bruggeman-Nannenga, M.A., Brugués, M., Cano, M.J., Enroth, J., Flatberg, K.I., Frahm, J.-P., Gallego, M.T., Garilleti, R., Guerra, J., Hedenäs, L., Holyoak, D.T., Hyvönen, J., Ignatov, M.S., Lara, F., Mazimpaka, V., Muñoz, J. \& Söderstrom, L. 2006. A annotated checklist of the mosses of Europe and Macaronesia. Journal of Bryology 28: 198-267.

Koponen, T. 1988. The phylogeny and classification of Mniaceae and Rhizogoniaceae (Musci). Journal of the Hattori Botanical Laboratory 64: 37-46.

Lewis, K. \& Smith, A.J.E. 1977. Studies on some bulbiferous species of Pohlia section Pohliella I. Experimental investigations. Journal of Bryology 9: 539-556.

Lewis, K. \& Smith, A.J.E. 1978. Studies on some bulbiferous species of Pohlia section Pohliella II. Taxonomy. Journal of Bryology 10: 9-27.

Nordhorn-Richter, G. 1982. Die Gattung Pohlia Hedw. (Bryales, Bryaceae) in Deutschland und den angrenzenden Gebieten 1. Lindbergia 8: 139-147.

Nyholm, E. 1958. Illustrated Moss Flora of Fennoscandia, vol. II, fasc. 3. CWK Gleerup, Lund.

Shaw, A.J. 1981a. The nomenclature of Pohlia annotina (Hedw.) Lindb. and related species. Lindbergia 7: 10-22.

Shaw, A.J. 1981b. A taxonomic revision of the propaguliferous species of Pohlia (Musci) in North America. Journal of the Hattori Botanical Laboratory 50: 1-81

Shaw, A.J. 1982. Pohlia in North and Central America and the West Indies. Contributions from the University of Michigan Herbarium 15: 217-295.

Shaw, A.J. 1984. Character analysis, phylogeny, and classification of the moss genus Pohlia. Canadian Journal of Botany 62: 219229

Shevock, J.R. \& Shaw, A.J. 2005. Pohlia robertsonii and P. rubunbaldenis (Bryopsida, Mniaceae), two new species from the Western and Eastern United States. The Bryologist 108: 177-182.

Smith, A.J.E. 2004. The moss flora of Britain and Ireland. Cambridge University Press. Cambridge.

Sotiaux, A. \& Arts, T. 1989. Pohlia andalusica (Höhn.) Broth. (Bryaceae), new for the Belgian moss flora. Dumortiera 43: 14-17.

Townsend, C.C. 1995. On the identity of Pohlia flexuosa Harv. with P. muyldermansii Wilcz. \& Dem. Journal of Bryology 18: 783-790.

Wilczek, R. \& Demaret F. 1970. Les Pohlia propagulifères de Belgique (Bryaceae). Bulletin du Jardin Botanique. National de Belgique. 40: 405-422.

Associate Editor: J. Shaw Received: 5-II-2007 Accepted: 10-V-2007 